\title{
Kidney Cancer pT3a TNM Finding v8
}

National Cancer Institute

\section{Source}

National Cancer Institute. Kidney Cancer pT3a TNM Finding v8. NCI Thesaurus. Code C140292.

Kidney cancer in which the tumor extends into the renal vein or its segmental branches, or invades the pelvicalyceal system, or invades perirenal and/or renal sinus fat but not beyond Gerota's fascia. (from AJCC 8th Ed.) 